\title{
Public-Private Partnerships in transport: a critical assessment of the Caribbean
}

\author{
Laura Panadès-Estruch \\ Truman Bodden Law School, George Town, Cayman Islands
}

\begin{abstract}
Purpose - This article critically analyses the extent to which selected Public-Private Partnerships (PPPs) transportation projects in the Caribbean subregion embrace good practices and how they benefit the public sector.

Design/methodology/approach - The article begins with the general rationale of PPPs, leading to a discussion on the specific challenges of the Caribbean subregion and an assessment of certain critical projects. The sample cases include the L F Wade International Airport in Bermuda, the cruise berthing and cargo port redevelopment project in the Cayman Islands, and the Sanger International Airport in Jamaica. There are five aspects to the critical assessment: (a) an evaluation of the type of PPP arrangement used; (b) the legal/policy framework; (c) financial implications; (d) accountability; and (e) miscellaneous data. Desk-based research is conducted as supported by both international and local sources to convey a uniquely local perspective in this under-researched area of scholarship.

Findings - PPP frameworks in the Caribbean are improving quickly but remain a work in progress. Jamaica leads the region. Bermuda trails behind. Problems of legal compliance with frameworks and limited market engagement persist, leading to risk management problems.

Originality/value - This article fills a literature gap on critical analysis of individual Caribbean PPP transportation projects. Previous reports, mostly by international organisations, cover regional or sectorial trends. Other sources take a descriptive but not critical approach.
\end{abstract}

Keywords Public-Private Partnerships (PPPs), Public procurement, Best practice, Offshore, Small states, Caribbean

Paper type Research paper

\section{Introduction}

Public-Private Partnerships (PPPs) are methods to provide public goods, works and services. They frequently entail long-term collaboration (e.g. 15 to 50 years), constant involvement of private partners throughout project development, complex underlying financing arrangements, payments over the life of the built assets to the private sector partners, optimal risk management involving effective risk transfer from the public to the private sector and public ownership of the infrastructure after the agreed contract tenure (European Commission, 2004; Yescombe and Farquharson, 2018). Definitions are varied within this framework. Digings and Bennett (2021) define them as "forms of cooperation between public

(C) Laura Panadès-Estruch. Published in Public Administration and Policy. Published by Emerald Publishing Limited. This article is published under the Creative Commons Attribution (CC BY 4.0) license. Anyone may reproduce, distribute, translate and create derivative works of this article (for both commercial and non-commercial purposes), subject to full attribution to the original publication and authors. The full terms of this license may be seen at http://creativecommons.org/licences/by/4.0/ legalcode

A word of thanks goes to the Chinese University of Hong Kong for inviting me to present my research at their July 2019 conference on 'Unpacking the complexity of regulatory governance' which inspired this article, and to the Cayman Islands Government for enabling my attendance. Many thanks to Hadleigh Roberts for proofreading this article. All errors and opinions are my own and do not represent the views of the Cayman Islands Government.
Caribbean PPPs in transport

Received 8 February 2021 Revised 23 February 2021 Accepted 2 March 2021
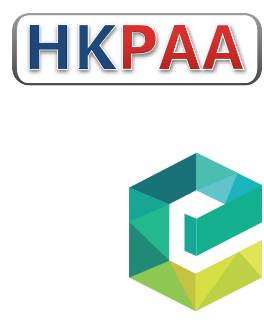

Public Administration and Policy Vol. 24 No. 1, 202 Emerald Publishing Limited 1727-2645 DOI 10.1108/PAP-02-2021-0004 
authorities and the private sector that have been used to modernise the delivery of public sector infrastructure and to deliver strategic public services across Europe". A widely accepted US definition of PPPs is the "procurement of a long-term contract for multiple elements that may include development (design and construction), operation and/or maintenance of a facility that involves a component of private financing" (US Department of Transportation - Federal Highway Administration, 2019, p. 2). Ultimately, whether a specific deal qualifies as a PPP requires a case-by-case analysis.

There are five main aspects to PPP evaluation: (a) the type of arrangement used; (b) the regulatory framework; (c) the financial implications of PPPs; (d) the accountability mechanisms; and (e) miscellaneous data. The first section of this article justifies the selection of variables.

To address the research question of whether the Caribbean jurisdictions are ready to welcome PPPs projects, this article critically evaluates selected PPP transport projects in the Caribbean which fills the literature gap on comparative PPP studies in this region. Caribbeanspecific features including limited fiscal space, tight constraints on financing, small size preventing economies of scale, vulnerability to natural disasters and climate change (Queyranne et al., 2019) justify a study of its own. Scholarly literature has assessed PPPs thoroughly in developed, mostly Western, jurisdictions. In contrast, the Caribbean subregion is under-researched. International organisation reports have focused on regional trends (Queyranne et al., 2019) and avoided criticising individual projects openly. This second section discusses the need for a Caribbean-centric study.

The third section justifies the choice of specific examples in Bermuda, the Cayman Islands and Jamaica. PPP arrangements are commonly used to procure hard infrastructure, frequently water and wastewater projects, roads, public transport and waste management (Akintoye et al., 2016) or social infrastructure projects such as schools, hospitals or prisons (Bergère, 2016). There are many challenges in the transportation sector because it is "an extremely inflexible investment" which cannot be easily traded or adjusted quickly to changing demand or transferred elsewhere, and one where the positive externalities of nonusers are extremely difficult to turn into project profit (Turró, 1999, pp. 233-234). The fourth section of this article applies the key variables for PPP studies to the selected sample.

This article is structured in four main sections, covering a literature review of public-private partnerships globally, the Caribbean context applied to PPPs, sample justification, and critical assessment of the PPP models in the selected sample. The methodology used is desk-based research based on legal and policy sources. Legislation and policy documents have been obtained from official, publicly managed online portals to guarantee reliability. Media sources have been used for support and further context. Notably, only top publications with a proven track record of quality have been used including the Jamaica Gleaner, the Royal Gazette in Bermuda and the Cayman Compass. A blend of international and local scholarship is used, including sources from vetted international organisations and top academics. The author, based locally in the Cayman Islands, has spared no effort to include relevant local sources.

\section{Mapping the trade-offs of Public-Private Partnerships}

This section explains what aspects of PPPs are important when critically assessing case studies. Relevant concepts of PPPs include the type of arrangement used, the regulatory framework, the financial implications of PPPs and the accountability mechanisms.

PPPs are common because it is an umbrella term rather than a fixed arrangement. PPPs are typically described with the range of tasks that have been allocated to the private sector. These commonly include a combination of design, build, finance, operation and management. PPPs frequently include a "DBFOM" PPP, where all five tasks have been allocated to the private sector; with variations including BOO for "build, own, operate", BOT meaning "build, operate, transfer", BTO standing for "build, transfer, operate", or BOOT as "build, own, operate, transfer" and, finally, DBFO entailing "design, build, finance, operate" (Yescombe, 2014; Yescombe and 
Farquharson, 2018, p. 13). Underpinning legal structures can also help define PPPs: common types comprise contractual and institutional PPPs. Contractual PPPs are those where a contract governs the relationship between the parties; institutional PPPs represent those cases where both the public and the private sector partners become shareholders in a third company (Yescombe, 2014). Concessions are sometimes classified as PPPs because they represent the "transfer of public rights to a promoter, private or otherwise" (Turró, 1999). This plurality of arrangements, rather than a fixed legal construct, is responsible for the worldwide spread of PPPs.

A second feature of successful PPPs is an ample regulatory margin. There are four key elements in creating a PPP framework: a clear policy orientation to deliver a long-term vision; a supportive institutional arrangement to build internal capacity in PPP procurement; a body of financial support measures that will attract private interest; and a legal and regulatory framework providing clarity in the parties' obligations as well as defining their rights (Verougstraete and Sekiguchi, 2017). Countries can choose whether to regulate PPPs either using law, policy or a combination of both (Delmon, 2015). For instance, the UK's PFI and PF2 were regulated mostly in policy and administrative documents; Spain's colaboración público-privada, now repealed, was mostly regulated in law. Others have combined law and policy. The Cayman Islands Public Management and Finance Act (2017 Revision) and the Financial Regulations (2013 Revision) define eligibility and financial constraints, and Government Ministries, Statutory Authorities and Government Companies define their own policies within the limits of the legislation.

The third factor is financial implications of PPPs. When well-managed, PPPs combine the public and private sector's strengths whilst delivering value for money. To achieve this, PPPs need early and accurate financial assessments. The PPP option should only be selected when it maximises value for money against all other forms of procurement. Structured finance determines which financial arrangement is to be applied to each specific PPP project, whereby "financing is based on a well-defined object, separated from the parties involved in the deal itself" (Gatti et al., 2012, p. 578). A popular stream of structured finance for PPPs is project finance, understood as a "lending technique that involves lending against the cash flow of particular projects" (Yescombe, 2013). Additionally, procurement managers should pursue value for money. Traditional public procurement criteria focused on selecting the lowest priced bid. This approach would put significant pressure on PPPs to deliver public projects at a profit for the private sector but at a low price for the public sector. Contractors would aim to push prices down when public procurement criteria were based solely on price. Välilä has described this trade-off as cost-savings of contract bundling versus 'the ability of the government to ensure that the private partner's zeal for cost-savings does not lead to an undue reduction in the quality of service' (Välilä, 2020). A new focus on value for money or the "most economically advantageous tender" has brought more suitable selection criteria.

The fourth factor is accountability. Potential PPP disadvantages may include the privatisation of public revenue, computing the whole-life costing of a PPP; whether the transfer of risk from the public to the private sector is effective and, ultimately, who can be held responsible for the financial failure and rescuing of a PPP; and their financing cost and potential for politicisation in the use of PPPs (Delmon, 2015). Institutions are often put in place to manage those risks. However, they are not one-size-fits-all and should be designed considering the needs and requirements of a specific jurisdiction.

The fifth factor is a miscellaneous section, including other information of interest. This item includes data that does not strictly fall under any of the other four categories but assists in assessing the PPP projects. This improves the quality of the results by focusing on context and practical aspects.

\section{Contextualising PPPs in the Caribbean}

The Caribbean hosts 31 mostly small, island countries, of heterogeneous economic performance, relying on commodity exports or tourism and subjected to extreme 
PAP

24,1

environmental risks (The World Bank, 2020). It combines sovereign states and former colonies from the United Kingdom, the Netherlands and France that became independent, though not sovereign, overseas territories. The specific challenges that PPPs face in the Caribbean, coupled with overarching literature gaps, justifies this study.

First, the Caribbean brings development challenges to PPPs. Most jurisdictions have small, remote and uncompetitive internal markets, overgrown public sectors and skint social security networks. Public revenue in most Caribbean countries is consumption-focused, relying among others, on high tariffs and administrative fees. Most rely on external trade and apply a comprehensive system of tariffs, such as Anguilla, Bermuda, the British Virgin Islands, the Cayman Islands, Montserrat and Turks and Caicos Islands. These dynamics make Caribbean countries highly vulnerable to risks in other countries.

Second, PPPs have a strategic role to play in the Caribbean. The combination of tax neutrality with fiscal restraint in most Caribbean countries forces them to seek innovative ways to afford projects with a high initial investment. Several Caribbean countries do not levy personal income tax or corporation tax. The Caribbean also hosts the highest regional concentration of offshore banking and finance centres worldwide, including 10 out of the 26 worldwide (International Monetary Fund, 2019). In addition, fiscal restraint has become a trend in the past decade, especially after the Global Financial Crisis of 2007-09 (Alleyne et al., 2011). Consequently, Caribbean infrastructure funding lags behind that of developed nations. Public sector investment decelerated in 2005-2015 from 10\% to 6.5\% of GDP (Queyranne et al., 2019) and a financing gap of USD 10.6bn is estimated for the 2014-2024 period (Caribbean Development Bank, 2014, p. viii).

The third reason is that infrastructures in the Caribbean lag behind international standards. A study commissioned by the International Monetary Fund argued on the importance of a legal framework for private participation to reduce risks but "most Caribbean countries do not have such legal provisions" (Queyranne et al., 2019, p. xii). In particular, a regional legal study found that competition is closer to a black letter law principle rather than a practice (Panadès-Estruch, 2020a). Additional challenges that the Caribbean brings to PPPs are lack of or limited technical expertise, risk assessment flaws and ineffective or limited risk transfer to the private sector, need of legal reform to attract private (foreign) investment and lack of funding for project advisors, conducive to unbearable fiscal risks to local governments (Queyranne et al., 2019).

This section has argued that challenges to local economies, a diminishing ability to raise public revenue and limited infrastructure endowments justify the interest on covering Caribbean PPPs. The next section focuses on sample selection.

\section{Selected sample}

PPPs are slowly making their way to Caribbean shores. In 2017, there were 48 ongoing PPP projects in Caribbean countries in different stages of development. Of those, $62.5 \%$ were in the concept stage, compared to only $16.7 \%$ under implementation (The World Bank et al., 2017). Caribbean PPP trends show that a majority of PPP models are based on private finance and user-paid fees and used mostly for transport infrastructure upgrading projects (PanadèsEstruch, 2019): transportation is the leading sector, comprising $37 \%$ of the projects and $45.91 \%$ of the capital expenditures (The World Bank et al., 2017).

This article's sample is diverse, and representative of key infrastructures and geographical, demographic and economic diversity. The sample has been designed to accommodate both ports and airports, the two key transportation infrastructures for island countries. Second, geographical spread within the Caribbean subregion has informed the sample. Jamaica and the Cayman Islands are located in the Caribbean sea. Bermuda is not strictly there, but it is often studied as part of the Caribbean subregion due to its common 
geography, weather, economics, leading productive sectors, legal development and local market characteristics. Third, these selected case studies represent diverse demographics: Bermuda and the Cayman Islands are small, with population not exceeding 65,000; whereas Jamaica's population exceeds 2.725 million in 2018 (Statistical Institute of Jamaica, 2020). Finally, the sample also considers economic diversity. Jamaica has the lowest GDP per capita, with USD 5,582; Bermuda and the Cayman Islands show figures well beyond that, with USD 117,089 and USD 85,975 in 2019 (The World Bank, 2021). This leads to a more representative and well-balanced sample.

PPPs are used across the Caribbean beyond the article's sample. The Bahamas has implemented government policy on PPP to "mobilise additional funding and financing sources" (Government of Bahamas, 2018). No PPP projects have started yet. The British Virgin Islands' procurement policy has enabled the use of PPPs and it is expected that the Terrance B. Lettsome International Airport expansion and redevelopment will be executed with a Design-Build-Finance PPP (Hearnden, 2015; Government of British Virgin Islands, 2016). The Turks and Caicos' Procurement Ordinance generally defines PPPs as based on any combination of public and private finance, with two PPP hospital locations and a new PPP-based CCTV system currently under way (Invest Turks and Caicos, 2020).

The first case study is Bermuda's L F Wade International Airport redevelopment project. Bermuda spans 150 islands and islets across 53.33 square kilometres with 64,000 inhabitants (Hendry and Dickson, 2018). It is also one of the British Overseas Territories, with a UK-appointed Governor as the supreme authority and with wide local self-governance powers (Hendry and Dickson, 2018). The first feature that makes Bermuda a relevant case study is that it is the latest territory among the sample in regulating PPPs: its framework entered into force on 2July 2018. Bermuda's geography is the second relevant item of this case study: a high number of widely spread-out islets lead to complex transportation needs provided its small landmass. Its many islands and islets are connected with a system including ferries, public buses, minibuses, taxis, rental cars, scooters and horse carriages (Bermuda Tourism Authority, 2020).

Bermuda's L F Wade international airport redevelopment is a 30 -year concession to manage the airport's operations, maintenance and commercial functions (Bermuda Airport Authority, 2017). The intended result is to enhance the passenger experience, improve retail and dining options, make spaces more accessible and expand flight routes (Bermuda Airport Authority, 2017). Facilities will revert to public ownership in 2047, upon contract tenure completion.

The Cayman Islands' cruise berthing facilities is the second selected case study. Cayman is one of the largest banking centres worldwide in terms of assets (Fichtner, 2016). It is a threeisland Caribbean country located to the south of Cuba, with numerous links to North, Central and South America, including the United States, Cuba and Panama. Like Bermuda, it is also a British Overseas Territory (Hendry and Dickson, 2018). Financial services and tourism drive the local economy (Cayman Islands Economics and Statistics Office, 2020). Cayman's interest is justified on having in place the most comprehensive framework yet to be put into practice. The Cayman Islands passed its Procurement Act in 2016, which did not enter into force until secondary legislation was passed in May 2018 (Cayman Islands Government, 2016; Cayman Islands Government, 2018a; Cayman Islands Government, 2018b). Cayman is planning to go ahead with another PPP outside of the transportation sector: the Integrated Solid Waste Management System (Cayman Islands Government, 2017).

Cayman's PPP case study is the cruise berthing and cargo port redevelopment facilities. It started in the early 2000s to replace current passenger tendering with direct boarding access from the cruise ship to the port terminal. The cruise berthing and cargo port redevelopment involves "two cruise piers or four berths; land reclamation adjoining the existing cruise and cargo area; the expansion of existing cargo facilities inclusive of quay walls, a RoRo jetty and 
PAP

24,1

\section{6}

dolphins; a cruise terminal and commercial buildings; and pavement for cargo quay, cruise terminal quay and the parking lot” (Cayman Islands Ministry of District Administration, Tourism and Transport, 2017). This project is currently suspended pending the outcome of a referendum on the project itself, as well as an ongoing constitutional review on its enabling law (Matrix Law Chambers, 2020). The future of the facilities is uncertain due to those ongoing constraints and COVID-19's impact on the cruise tourism sector.

The third case study is Jamaica's Sangster International Airport. Jamaica is an island country located in the Caribbean sea, to the south of Cuba. The first interesting factor about this country is that geographically, it is the largest among the sample, at a land mass of 11,424 square kilometres and with a population close to three million (Bank of Jamaica, 2017; Statistical Institute of Jamaica, 2020). The second factor is that it is the only country among the sample that is not a British Overseas Territory, though it was in the past. Jamaica was colonized by the British in 1655 and it gained independence in 1962. Thirdly, Jamaica has the oldest colonized public procurement framework, with laws going back to the mid-1980s. Lastly, the local economy is based on services, accounting for more than $70 \%$ of GDP, and with a balance of payments reliant on tourism (Statistical Institute of Jamaica, 2021). The chosen case study is relevant as the country's "largest airport and gateway to the island's tourist industry" (Simon, 2015, p. 39), providing access to its tourism resorts on the north coast (Caribbean Development Bank, 2014, p. 26).

Many regard the Sangster International Airport as a complete success. No strong criticism is found in the literature, as institutions such as the World Bank and the Caribbean Investment Bank support it without reservation. Under the previous public ownership and management, the airport was ageing and crowded, with the airport's operations becoming "a significant drain" in the public budget at a time when debt was "high and rising" (Caribbean Development Bank, 2014). Sangster is a Jamaican transportation PPP involving the Government of Jamaica and the Vancouver Airport Services Consortium to deliver management, operations, financing and capital improvements of the airport, with assets reverting back to public ownership after 30 years (The World Bank et al., 2017). The project has reached its first half of the contract tenure, delivering significant private investment, doubling airport capacity to seven million passengers yearly and providing 43 new retail spaces (The World Bank et al., 2017).

\section{Critical assessment of the selected projects}

This section critically evaluates the sample according to five variables: the type of arrangement used, the regulatory framework, the financial implications of PPPs, the accountability mechanisms and miscellaneous data.

\section{PPP types}

The Caribbean is moving towards pure PPPs and beyond concessions, showing a more innovative, hands-on approach. The sample includes two pure PPPs out of the three cases. Pure PPPs, including contractual and institutional, are based on a continuous partnership that keeps the public and the private sector partners cooperating through the project tenure. Bermuda and Cayman, with their airport and port respectively, starting after 2015, are pure PPPs. Concessions are arrangements where the private partner leads the project and takes key decisions, with the public sector excising oversight only. All deals show lengthy contract tenures, of either 25 or 30 years, as expected. Jamaica's Sangster Airport, starting in 2003, played it safe by using a concession.

The L F Wade International Airport redevelopment is a 30-year Design-Build-FinanceOperate-Maintain PPP which started in 2017 (Bermuda Airport Authority, 2020). This model represents one of the most complete PPP arrangements, the DBFO, with its initials 
representing the four functions grouped under contract (Yescombe, 2014; Yescombe and Farquharson, 2018: 13). With it, the Bermudian Government is using one of the most comprehensive PPP arrangements available. Project delivery is managed via a partnership between a public sector entity, the Bermuda Airport Authority; and Bermuda Skyport Corporation Limited (Skyport), a special purpose Bermudian company owned by the Canadian company Aecon Concessions (Bermuda Airport Authority, 2020).

The cruise berthing facilities and cargo port redevelopment PPP contract is a DesignBuild-Finance-Operation contract for 25 years starting from asset construction (Cayman Islands Ministry of District Administration, Tourism and Transport, 2017). Verdant Isle Port Partners won the project award in 2019. This is a consortium of four companies led by Carnival and Royal Caribbean, among the largest cruise ship companies worldwide and the top companies for cruise calls in Cayman (Panadès-Estruch, 2020b). The project is currently suspended due to legal and political challenges and a final decision will be taken only after the May 2021 general elections (Panadès-Estruch, 2020b). Given the information publicly available, the project is likely to go ahead as a contractual PPP, with a contract detailing the regime of rights and obligations to apply to the parties.

Jamaica's Sangster Airport is a 30-year concession contract which started in 2003 (Caribbean Development Bank, 2014), where a limited liability company operates the airport (Simon, 2015), users pay the airport's fees (Queyranne et al., 2019) and the public sector retains ownership (Airports Authority of Jamaica, 2020). This deal came after a failed attempt at privatisation under the Cabinet's approval and direction of the National Investment Bank of Jamaica (Caribbean Development Bank, 2014). Concessions representing the outsourcing of soft infrastructure (i.e. services) are not PPPs. The concessionaire, MBJ Airports Limited, is a private company whose equity was originally controlled by Abertis Infraestructuras SA in 2014, a globally leading Spanish infrastructure provider, with $74.5 \%$ of equity, and Vantage Airport Group, with 25.5\% of equity (MBJ Airport, 2020). In 2014, Abertis divested from the airport sector and sold its stake to Grupo Aeroportuario del Pacifico (Browne, 2014; Grupo Aeroportuario del Pacifico, 2020), a Mexican company and also concessionaire of Norman Manley International Airport. The Airports Authority of Jamaica retains ownership and is responsible for regular performance reviews and contract administration oversight (Airports Authority of Jamaica, 2020).

\section{Regulatory framework}

Regulatory frameworks should aim to be comprehensive and enforceable, rather than striking a prescribed balance between law and policy. Jamaica, with the longest PPP experience, shows the most comprehensive framework. Bermuda and Cayman have succinct PPP regulation and rely heavily on their general procurement frameworks, still under construction.

Bermuda's regulatory framework is based on the Code of Practice for Project Management and Procurement (Government of Bermuda Office of Project Management and Procurement, 2018). The Code entered into force in July 2018. There is no specific PPP regulation but, as "high value procurement", they require competitive procurement procedures. The competitive procurement requirement can be waived, but only upon written request of the Authorised Officer (i.e. the project owner) and with the written approval of the Director of Procurement, who retains the option of consulting the Accountant General or the Financial Secretary. In addition, PPP procurement shall be reported to the designated procurement office prior to any advertisement, presumably for compliance reasons. Specific PPP regulations shall be included in the future, developing further the eligibility of projects for PPP procurement, or introducing enhanced safeguards in managing finance and risks of PPP projects. The framework needs development. 
PAP

24,1

68

The Cayman Government has largely complied with what is expected of procurement in the current legislative framework but out of goodwill, rather than enforceability. PPP regulation in Cayman is succinct, mostly enshrined in Law and not applicable to its cruise berthing facilities. PPPs were foreseen for the first time in 2013, when the Public Management and Finance Act (2013 Revision) (Cayman Islands Government, 2013) determined four conditions for PPP eligibility, which function as financial safeguards and will be reviewed in the next subsection. In turn, PPPs are excluded for projects with "a lifetime value of less than CI $\$ 15$ million" (EUR 15.05 million, USD 18 million) and for "projects where the fast pace of change in the sector makes it difficult to effectively define the outputs it requires in a long-term contract" (Cayman Islands Government, 2013). The cruise berthing's procurement started in 2015. The legal framework for procurement, the Procurement Act and its Regulations, entered into force three years after that, in May 2018 (Cayman Islands Government, 2016; Cayman Islands Government, 2018a; Cayman Islands Government, 2018b).

Jamaica is the sampled country with the most comprehensive public procurement system. A combination of legal and policy framework, Jamaica has the Public Procurement Act 2015 and its 2018 Revision (Government of Jamaica - Houses of Parliament, 2015; Government of Jamaica - Houses of Parliament, 2018a), its 2018 Regulations (Government of Jamaica Houses of Parliament, 2018b) and a suite of supporting policies. The only specific reference to PPPs within the legal and policy framework is entitling the minister in charge, subject to the Cabinet's approval, to exclude PPPs from complying with the procurement's legal framework (Government of Jamaica - Houses of Parliament, 2015, s.3.3.a). On the one hand, this is reassuring, as having no specific provisions for PPP makes them fall under the full remit of procurement procedures and their safeguards. On the other hand, providing the option of excluding PPPs from compliance with the legal framework is problematic, despite requiring the Cabinet's support. This lack of specific legal and policy regimes for PPPs has been compensated with oversight institutions, which will be covered under "accountability".

\section{Financial safeguards}

This aspect considers whether the sample has mechanisms to manage the financial implications of PPP. PPPs are long-term agreements with underlying complex financial arrangements. All jurisdictions should aim to have financial rules that help to assess whether the PPP debt is to be considered on or off-balance sheet and, especially when on balance sheet, to make sure that PPP-related long-term financial commitments are adequately foreseen and managed. IMF-commissioned research concluded that most Caribbean countries have frameworks which do not assess fiscal risks at key project stages (Queyranne et al., 2019), with Jamaica being the only exception among the sample. However, minimum safeguards for long-term sustainability of public finances have been set in all the sampled countries.

Bermuda's L F Wade International Airport represented a fair fiscal commitment, but with warnings. The Fiscal Responsibility Panel, a panel of three independent evaluators, issued a report in 2015 stating that the L F Wade PPP would not require public spending. However, it would involve "the loss of airport revenues net of operating costs over the medium and longer term" and shall be offset by fiscal measures which increase revenue (Peretz et al., 2015). By 2019, PPPs were still on the docket for Bermuda: the same Fiscal Responsibility Panel pointed out the low share of domestic investment and the need to "become more innovative in sourcing financing for future projects" including, among others, PPPs (Portes et al., 2019, p. 26). The same 2019 report highlighted the need for the government to set "clearly and transparently" its fiscal strategy and targets (Portes et al., 2019, p. 29).

The Cayman Islands has been an advocate for good fiscal management since 2013 when the Framework for Fiscal Responsibility was made binding. All PPP costs must comply with the general financial rules, so net debt (i.e. the total outstanding value of public borrowing minus liquid assets) does not exceed $80 \%$ of operating revenue and ability to borrow to fund 
capital expenditure restricted to projects with sufficient expected revenues or when sufficient surplus can be demonstrated (Cayman Islands Government, 2012). The Law also determines four PPP-specific financial safeguards (Cayman Islands Government, 2013). First, "a sound appraisal underpinning the proposed project before the financing means has been determined" shall justify the need for the project. Second, it is also necessary for PPPs to deliver "improved value for money against a conventionally financed alternative". This is equivalent to the public sector comparator considered previously in this article, whereby PPP financing must project better results than public financing - that is, if the government could afford the project from public budget allocations or could obtain better financing conditions without involving private partners. Third, a "long-term affordability case [which] has been assessed and agreed by the appropriate technical experts retained by the Cayman Islands Government" shall demonstrate the financial viability of the project. Fourthly and finally, "an independent opinion [...] from a qualified accountant of good standing on the correct accounting treatment in the Cayman Islands Government's accounts" is required to make sure PPPs are correctly accounted for. Additionally, "the Cayman Islands Government will retain independent accounting, legal, financial, economic, environmental and other technical advice as appropriate to ensure value for money" in all PPP projects.

Jamaica has been praised as one of the five countries in the Caribbean which "assess[es] fiscal risks in key project stages [including] at project selection, tender preparation, contract negotiation and renegotiations, and contract extension" (Queyranne, et al., 2019, p. 51). For PPPs, the Public Bodies Management and Accountability Act (2014 Revision) sets specific accounting rules and requires the approval of the Cabinet on recommendation of the Public Investment Management Committee (Government of Jamaica - Ministry of Finance and the Public Service, n.d.). Applicable laws also require contingencies for PPPs, up to $8 \%$ of GDP after April 2017. Financially, by 2017, the Sangster concession had brought over USD 200 million in facilities' improvement and expansion, including 43 new commercial retail spaces, leading to doubling the airport's capacity to 7 million passengers annually (The World Bank et al., 2017).

\section{Accountability}

The three jurisdictions rely on oversight bodies to make sure that PPPs are kept accountable. It is impossible to assess a project wholly until its end and all these examples are still underway. In 2020, they have all implemented similar central procurement bodies, namely a designated procurement office within their respective governments. Jamaica offers the strongest accountability network, with two PPP-specific bodies designed to overcome conflicts of interest between PPP promotion and accountability. Cayman and Jamaica have also implemented civil society panels to review high-value projects. Though Bermuda is lagging, cross-fertilisation is high across the sample and leads to opportunities to learn from each other.

Bermuda has no dedicated PPP unit, but has a designated public procurement body: the Office of Project Management and Procurement (OPMP). The Office centralises public procurement oversight, guidance and support across the Government (Government of Bermuda Office of Project Management and Procurement, 2018). There are no records of other general procurement or specific PPP units other than the OPMP.

Cayman's Procurement Act 2016 has established additional administrative structures to improve public procurement. Two new administrative bodies have been created. The Central Procurement Office is tasked with "providing training, advice and guidance to all entities and persons involved in public procurement" (Cayman Islands Government, 2016). The Public Procurement Committee (PPC) is a group of eight members entrusted to review public procurement documentation for contracts exceeding a value of $\mathrm{CI} \$ 250,000$ and direct awards with values exceeding CI\$100,000 (Cayman Islands Government, 2016). The Committee is 
PAP

24,1

also responsible for assessing recommended awards over these thresholds: if approved, the project can go ahead; otherwise, the project owner can either accept the PPC's refusal or proceed with its own recommendation so long as it is accompanied by a written notification stating the reasons why. These two entities promote public oversight and assist in engaging the general public into procurement matters. PPPs are excluded for projects under CI\$15 million; consequently, they fall under the PPC's oversight.

Jamaica has two PPP-specific units within the Government, which separate PPP promotion and oversight, leading to improvements in managing institutional conflicts of interest: one within the Development Bank of Jamaica, charged with business case development, the PPP's transaction phase and the day-to-day administration, including advisory, financial and managerial support; the second PPP-specific unit is responsible for assessing value for money and fiscal impact within the Ministry of Finance and the Public Service (Government of Jamaica - Ministry of Finance and the Public Service, n.d.; Queyranne et al., 2019). General bodies, such as the Office of Public Procurement and the Public Procurement Commission complete the system and are equivalent to the Central Procurement Office and the Public Procurement Committee of the Cayman Islands.

\section{Miscellaneous data}

This section covers data concerning the performance of the projects that does not fall strictly in any of the categories considered previously, intending to reflect on the challenges that PPPs face in the Caribbean. The sample shows remaining concerns regarding the robustness of procurement compliance, mostly affecting relationship management between the Government and the selected private partners or concessionaires.

Concerns with the L F Wade International Airport have been raised regarding the lack of competitive bidding, a process which was based on an unsolicited proposal and is deeply concerning (Fisher, 2018). Richards, the then Minister of Finance, defended the decision based on the inability of the Bermudian Government to compensate unsuccessful bidders for the expenses incurred (Johnston, 2018). The Bermuda Public Services Union (2015) highlighted additional problems regarding poor value for money compared to other forms of procurement, cost underestimation in affordability analyses and limited private sector appetite and bankability, which Richards also dismissed due to necessary constraints from the low figures of passengers, in comparison to those shown in more experienced PPP markets (Johnston, 2018).

The main concern regarding the cruise berthing facilities in Cayman is the voluntary compliance of the project with the legal framework. As explained above, the project started before the legal framework became enforceable. Thus, compliance relies on the Government's goodwill, rather than the law. A remaining concern is that, in 2020, Cayman has no PPP experience. However, the Government expects to be ready when the time comes. The local Government has training programmes for civil servants through the Civil Service College, provides access to the online training platform of the United Kingdom's civil service and plans to collaborate with the University College of the Cayman Islands to provide island-wide training opportunities (Panadès-Estruch, 2020a).

Jamaica's airport privatisation has been driven by a concessionaire. Its two largest airports, Norman Manley and Sangster International Airports, are operated under 30-year concessions. The Sangster concession agreement was signed in April 2003. Six months later, in October 2003, Norman Manley International Airport's concession agreement followed, with concessionaire Grupo Aeroportuario del Pacifico (Airports Authority of Jamaica, 2020). The Jamaican government justifies the concessions as "in keeping with international trends and the need to attract private capital to finance the required levels of expansion and development [...] to cope with the projected growth in aircraft and passenger traffic" (Airports Authority of Jamaica, 2020). However, this is a risky strategy: entrusting the two 
international airports of the country and, since 2014, to the same concessionaire is, at least risky and at most imprudent.

\section{Conclusion}

Caribbean PPPs are rapidly improving, but legal and policy frameworks need further work. This article sets out to find out whether the Caribbean is ready to welcome PPP projects. The Caribbean area is relying more on PPPs to deliver projects that would otherwise be unaffordable, but it needs to develop ways to achieve accountability and maximising value for money. Based on five variables: (a) the type of PPP; (b) regulatory framework; (c) financial safeguards; (d) accountability; and (e) miscellaneous data, this article has three key findings. First, accountability and publicity need to be enhanced. Second, market engagement needs to be improved. Third, implementation of legal and institutional frameworks has unearthed issues that need to be corrected. Figure 1 summarises the findings as discussed and highlights the areas with shortcomings. Whereas this is normal, local law-makers have to introduce the necessary adjustments as early as possible.

Jamaica's record is good, but not perfect. Jamaica has shown the most consistent, comprehensive framework. Its record track of PPPs is praised by many (ICAO, 2015; Samuel, 2019; David-Barrett, 2020), its regulatory framework largely places PPPs within the public procurement framework with no special treatment, and the possibility of excluding PPPs from legal compliance is largely compensated with financial contingencies and PPP-specific institutions. However, time will tell whether using the same concessionaire for both international airports will pay off. The concessionaire's market capture might lead to issues in one airport also affecting the other. Should this happen, the Jamaican Government's position would have little room for negotiation. The Cayman Islands ranks better in preparedness than action. Their procurement framework, largely reliant on legislation, is up to the task, and its civil servants are training on procurement. Nevertheless, PPPs are seen more as a last resort rather than a default option and, consequently, none has moved beyond partner selection in 2020. The system looks good, but remains untested. Bermuda is unconvinced on whether PPPs can truly take off due to systemic restrictions, either of geographical nature or due to lack of administrative capacity. However, the Bermudian Government should stop using this as an excuse to move ahead in implementing a

\begin{tabular}{|c|c|c|c|c|c|}
\hline Variables & PPP type & $\begin{array}{l}\text { Regulatory } \\
\text { framework }\end{array}$ & $\begin{array}{l}\text { Financial } \\
\text { safeguards }\end{array}$ & Accountability & Project concerns \\
\hline $\begin{array}{l}\text { Bermuda's } \\
\text { L F Wade } \\
\text { International } \\
\text { Airport }\end{array}$ & $\begin{array}{l}\text { contractual } \\
\text { DBFO PPP, } \\
30 \text { years }\end{array}$ & $\begin{array}{l}\text { policy, needs } \\
\text { development }\end{array}$ & $\begin{array}{l}\text { concerns about } \\
\text { value for } \\
\text { money and } \\
\text { fiscal } \\
\text { sustainability }\end{array}$ & $\begin{array}{l}\text { central } \\
\text { designated } \\
\text { procurement } \\
\text { office }\end{array}$ & $\begin{array}{l}\text { compliance with } \\
\text { procedures }\end{array}$ \\
\hline $\begin{array}{l}\text { Cayman's } \\
\text { Cruise } \\
\text { berthing and } \\
\text { cargo port } \\
\text { redevelopment } \\
\text { project }\end{array}$ & $\begin{array}{l}\text { contractual } \\
\text { DBFO PPP, } \\
25 \text { years }\end{array}$ & law and policy & $\begin{array}{l}\text { debt capped \& } \\
\text { conditioned; } \\
\text { PPP-specific } \\
\text { safeguards }\end{array}$ & $\begin{array}{l}\text { government } \\
\text { and civil } \\
\text { service } \\
\text { oversight } \\
\text { institutions }\end{array}$ & $\begin{array}{l}\text { framework not } \\
\text { binding to the } \\
\text { project, remains } \\
\text { untested }\end{array}$ \\
\hline $\begin{array}{l}\text { Jamaica's } \\
\text { Sangster } \\
\text { International } \\
\text { Airport }\end{array}$ & $\begin{array}{l}\text { concession, } \\
30 \text { years }\end{array}$ & law and policy & $\begin{array}{l}\text { specific } \\
\text { accounting } \\
\text { treatment; PPP- } \\
\text { specific } \\
\text { contingencies }\end{array}$ & $\begin{array}{l}\text { institutional } \\
\text { separation } \\
\text { between PPP } \\
\text { promotion and } \\
\text { assessment }\end{array}$ & $\begin{array}{l}\text { risk } \\
\text { management: } \\
\text { same } \\
\text { concessionaire } \\
\text { for both } \\
\text { international } \\
\text { airports }\end{array}$ \\
\hline
\end{tabular}

Caribbean PPPs in transport

\section{transport}

71


PAP

24,1

comprehensive accountability framework and start setting fiscal targets to move ahead with PPPs. Their frameworks show flaws in policy, ensuring value for money and fiscal sustainability. In addition, compliance mechanisms need reinforcing. Among the countries in sample, they are the one that needs to work harder to solve the issues identified in this article.

This study faced usual limitations regarding the sample selection, the access to data and the different stages of project completion. The sample is fair, comprising a diverse, representative pool of projects. International organisation reports already cover regional general trends and it is precisely from narrowing it down to the detailed study of a sample where the article adds value. Regarding access to data, this has to do with the article finding that publicity and reporting need to improve in the Caribbean. The article engaged with all main sources, especially local ones. On the different stages of each project, researchers will be able to evaluate the projects with certainty only after project completion.

PPPs in the Caribbean are not exempted when it comes to squaring the circle between increasing budgetary demands and raising investment in public goods, works and services. Caribbean countries are taking great strides provided their limitations. The question is whether they are working on safe havens or sinking ships. For the moment, they are working on the latter.

\section{ORCID iDs}

Laura Panadès-Estruch (Dhttp://orcid.org/0000-0001-5277-9253

\section{References}

Airports Authority of Jamaica (2020), "Our business", available at: https:/airportsauthorityjamaica. aero/our-business/ (accessed 10 July 2020).

Akintoye, A., Beck, M. and Kumaraswamy, M. (2016), Public Private Partnerships: A Global Review, Routledge, Abingdon.

Alleyne, D., Lugay, B. and Dookie, M. (2011), "The relationship between fiscal and current account balances in the Caribbean", available at: https://repositorio.cepal.org/bitstream/handle/11362/ 4084/1/S2011925_en.pdf (accessed 20 June 2020).

Bank of Jamaica (2017), "Jamaica in figures 2017”, available at: http://boj.org.jm/uploads/pdf/jam_ figures/jam_figures_2017.pdf (accessed 21 February 2021).

Bergère, F. (2016), "Ten years of PPP: an initial assessment", available at: https:/library. pppknowledgelab.org/documents/2851/download (accessed 20 June 2020).

Bermuda Airport Authority (2017), "The company", available at: https://bermudaairport.com/aboutskyport/the-company/ (accessed 20 June 2020).

Bermuda Airport Authority (2020), "Public-Private Partnership", available at: https://www. airportauthority.bm/redevelopment/public-private-partnership.html (accessed 20 June 2020).

Bermuda Public Services Union (2015), "BPSU Report: Public-Private Partnerships", available at: https://docs.wixstatic.com/ugd/716820_56c18ed328e2496d9afb115a787e0278.pdf (accessed 20 June 2020).

Bermuda Tourism Authority (2020), "Transportation”, available at: https://www.gotobermuda.com/ transportation (accessed 20 June 2020).

Browne, R. (2014), "Major investor selling Sangster airport stake”, available at: http:/jamaica-gleaner. com/gleaner/20140319/business/business1.html (accessed 10 July 2020).

Caribbean Development Bank (2014), "Public-Private Partnerships in the Caribbean - building on early lessons", available at: https://www.caribank.org/publications-and-resources/resourcelibrary/thematic-papers/public-private-partnerships-caribbean-building-early-lessons (accessed 3 January 2021). 
Cayman Islands Economics and Statistics Office (2020), "Indicators: GDP by industrial origin", available at: https://www.eso.ky/data/files/GDP\%20by \%20Industry $\% 20$ (Constant $\%$ 20Prices)\%202019.xlsx (accessed 21 February 2021).

Cayman Islands Government (2012), "Framework for fiscal responsibility", available at: http://www. standardsinpubliclifecommission.ky/fronthome/download?file=CaymanIslandsFramework forFiscalResponsibility_1476988889.pdf (accessed 20 June 2020).

Cayman Islands Government (2013), "The Cayman Islands Public Management and Finance Act (2013 Revision)", available at: http://www.gov.ky/portal/pls/portal/docs/1/11525779.PDF (accessed 20 June 2020).

Cayman Islands Government (2016), “The Procurement Act”, available at: https://www.procure.gov. ky/procurement-law (accessed 20 June 2020).

Cayman Islands Government (2017), "The Public Management and Finance Act (Amendment) (No. 2) Act”, available at: https://www.procure.gov.ky/fronthome/download?file=managementlaw_ 1515174389.PDF (accessed 20 June 2020).

Cayman Islands Government (2018a), "The Procurement Regulations", available at: https:/www. procure.gov.ky/procurement-regulations (accessed 20 June 2020).

Cayman Islands Government (2018b), “The Procurement Act, 2016 (Commencement) Order, 2018”, available at: http://www.gov.ky/portal/pls/portal/docs/1/12604408.PDF (accessed 20 June 2020).

Cayman Islands Ministry of District Administration, Tourism and Transport (2017), "Cruise berthing facility - prequalification of bidders", available at: https://cayman.bonfirehub.com/ opportunities/3525 (accessed 20 June 2020).

David-Barrett, L. (2020), "Building public procurement integrity in Jamaica”, (11 February 2020), Global Integrity - Blog, available at: https:/www.globalintegrity.org/2020/02/11/buildingpublic-procurement-integrity-in-jamaica/ (accessed 20 June 2020).

Delmon, J. (2015), Private Sector Investment in Infrastructure: Project Finance, PPP projects and PPP frameworks, Wolters Kluwer, Alphen on the Rhine.

Digings, L. and Bennett, J. (2021), EU Public Procurement: Law and Practice, Sweet and Maxwell, Oxford.

European Commission (2004), Green Paper on Public-Private Partnerships and Community Law on Public Contracts and Concessions, European Commission, Brussels.

Fichtner, J. (2016), "The anatomy of the Cayman Islands offshore financial center: Anglo-America, Japan, and the role of hedge funds", Review of International Political Economy, Vol. 23 No. 6, pp. 1034-1063.

Fisher, L. (2018), "L F Wade International Airport Redevelopment Project - Project Agreement Review - Findings Report”, available at: https://www.gov.bm/sites/default/files/2018-02-11_\%20PA\% 20Review_Report.pdf (accessed 20 June 2020).

Gatti, S., Caselli, S. and Steffanoni, A. (2012), "Project finance" in Cumming, D., The Oxford Handbook of Entrepreneurial Finance, Oxford University Press, Oxford, pp. 578-610.

Government of Bahamas (2018), "Public-Private Partnerships policy", available at: https:/www. bahamas.gov.bs/wps/wcm/connect/5a74940c-6125-406c-8140-5584eaf525d4/Public +Private+Pa rtnerships+Policy+Sept+2018.pdf?MOD=AJPERES (accessed 20 June 2020).

Government of Bermuda Office of Project Management and Procurement (2018), "Code of practice for project management and procurement", available at: https://www.gov.bm/sites/default/files/ 20181015-Code-of-Practice-for-Project-Management-and-Procurement.pdf (accessed 20 June 2020).

Government of British Virgin Islands (2016), "Expansion of the Terrance B. Lethsome airport: outlined business case", available at: http://www.bvi.gov.vg/pub/BVI\%20TBLIA $\% 20$ Expansion $\% 20-\%$ 20Outlined \%20Business \%20Case \%20-\%20May\%202016.pdf (accessed 20 June 2020).

Government of Jamaica - Houses of Parliament (2015), "Public Procurement Act 2015", available at: https://japarliament.gov.jm/attachments/article/341/The $\% 20$ Public $\% 20$ Procurement $\% 20 \mathrm{Act}, \%$ 202015.pdf (accessed 20 June 2020). 
PAP

24,1

Government of Jamaica - Houses of Parliament (2018a), "Public Procurement Act (2018 Revision)", available at: https://japarliament.gov.jm/attachments/article/341/The $\% 20 \mathrm{Public} \%$ 20Procurement \%20(Amendment)\%20Act, \%202018\%20No.\%2012.pdf (accessed 20 June 2020).

Government of Jamaica - Houses of Parliament (2018b), “The Public Procurement Regulations 2018”, available at: https://japarliament.gov.jm/attachments/article/530/The $\% 20 \mathrm{Public} \%$ 20Procurement\%20Regulations, \%202018.pdf (accessed 20 June 2020).

Government of Jamaica - Ministry of Finance and the Public Service (n.d.), "Jamaica's Public-Private Partnership programme”, available at: https:/mof.gov.jm/downloads/programmes/publicprivate-partnerships/jamaica-ppp-programme.pdf (accessed 20 June 2020).

Grupo Aeroportuario del Pacífico (2020), "Press releases: Grupo Aeroportuario Del Pacífico, S.A.B. de C.V. announces agreement for the acquisition of Spanish company DCA", available at: https://www. aeropuertosgap.com.mx/en/material-events/2208-dca-aquisition.html (accessed 21 February 2021).

Hearnden, N.D. (2015), "Procurement in the British Virgin Islands", available at: https://assets. publishing.service.gov.uk/government/uploads/system/uploads/attachment_data/file/415905/ Procurement_in_the_British_Virgin_Islands___Final.pdf (accessed 20 June 2020).

Hendry, I. and Dickson, S. (2018), British Overseas Territories Law, Hart Publishing, Oxford.

ICAO (2015), "Public-Private Partnership - Case study", available at: https://www.icao.int/ sustainability/PPP\%20Case\%20Studies/PPP_Airport_Jamaica.pdf (accessed 20 June 2020).

International Monetary Fund (2019), "Past IMF Staff Assessments on Offshore Financial Centers (OFCs)", available at: https://www.imf.org/external/np/ofca/ofca.aspx (accessed 20 June 2020).

Invest Turks and Caicos (2020), "Healthcare”, available at: https://www.investturksandcaicos.tc/ healthcare-turks-caicos/ (accessed 20 June 2020).

Johnston, P. (2018), "Richards talks down tender for airport", 12 May, available at: http://www. royalgazette.com/news/article/20180312/richards-talks-down-tender-for-airport-deal (accessed 15 July 2020).

Matrix Law Chambers (2020), "Cayman Islands Referendum Law held unconstitutional”, available at: https://www.matrixlaw.co.uk/news/cayman-islands-referendum-law-held-unconstitutional/ (accessed 20 June 2020).

MBJ Airport (2020), "About us”, available at: https://www.mbjairport.com/about-mbj (accessed 10 July 2020).

Panadès-Estruch, L. (2019), "Assessing Public-Private Partnership law and regulation in the Cayman Islands: opening gateways or closing loopholes?”, Public-Private Partnership Law Review, Vol. 28 No. 3, pp. 108-119.

Panadès-Estruch, L. (2020a), "Competition in British Overseas Territories: Going for gold or a race to the bottom?”, European Public-Private Partnership Law Review, Vol. 15 No. 1, pp. 13-23.

Panadès-Estruch, L. (2020b), "The Cayman Islands cruise berthing - an unfinished drama in three acts", Études Caribéennes, Vol. 47 No. 1, available at: https://journals.openedition.org/ etudescaribeennes/19612 (accessed 21 February 2021).

Peretz, D., Heller, P.S. and Portes, J. (2015), "Fiscal responsibility panel: Bermuda - annual assessment 2015”, available at: http://parliament.bm/admin/uploads/report/76e7f6c4940fb15a1fe8cbd3 1980f91e.pdf (accessed 20 June 2020).

Portes, J., Bell, M. and Heller, P.S. (2019), "Fiscal responsibility panel: Bermuda - annual assessment 2019", available at: https://www.gov.bm/sites/default/files/11242-Fiscal-Responsibility-PanelAnnual-Assessment-2019.pdf (accessed 20 June 2020).

Queyranne, M., Daal, W. and Funke, K. (2019), Public-Private Partnerships in the Caribbean RegionBringing the Benefits while Managing Fiscal Risks, International Monetary Fund, Washington D.C.

Samuel, S.B. (2019), "Incautious Optimism: things are looking great for PPPs in the Caribbean", 17 July, available at: https://blogs.worldbank.org/ppps/incautious-optimism-things-are-lookinggreat-ppps-caribbean (accessed 20 June 2020). 
Simon, J. (2015), "Public-Private Partnerships enable infrastructure development", ICAO Journal, Vol. 70 No. 4, pp. 38-39.

Statistical Institute of Jamaica (2020), "Population statistics", available at: https://statinja.gov.jm/ Demo_SocialStats/Newpopulation.aspx (accessed 20 June 2020).

Caribbean PPPs in transport

Statistical Institute of Jamaica (2021), "Fiscal Year Gross Domestic Product And Value Added (By Industry) at Current Prices", available at: https:/statinja.gov.jm/NationalAccounting/Quarterly/ NewQuarterlyGDP.aspx (accessed 21 February 2021).

The World Bank, Multilateral Investment Fund - IDB Group, Caribbean Development Bank, Inter-American Development Bank and PPIAF (2017), Caribbean Public-Private Partnerships Toolkit - Developing Infrastructure and Improving Service Delivery, International Bank for Reconstruction and Development, Washington D.C.

The World Bank (2020), “The World Bank Group and the Caribbean”, available at: https://www. worldbank.org/en/country/caribbean/overview (accessed 11 June 2020).

The World Bank (2021), "GDP per capita (current US\$)”, available at: https://data.worldbank.org/ indicator/NY.GDP.PCAP.CD (accessed 2 January 2021).

Turró, M. (1999), Going Trans-European - Planning and Financing Transport Networks for Europe, Pergamon, London.

US Department of Transportation - Federal Highway Administration (2019), "Public-Private Partnership Procurement: a guide for public owners", available at: https://www.fhwa.dot.gov/ ipd/pdfs/p3/toolkit/p3_procurement_guide_0319.pdf (accessed 20 June 2020).

Välilä, T. (2020), "An overview of economic theory and evidence of Public-Private Partnerships in the procurement of (transport) infrastructure", Utilities Policy, Vol. 62, p. 100995.

Verougstraete, M. and Sekiguchi, J. (2017), "PPP policy, legal and institutional frameworks in Asia and the Pacific", available at: https:/www.unescap.org/sites/default/files/PPP\%20Policy-LegalInstitutional\%20Frameworks_2017.pdf (accessed 20 June 2020).

Yescombe, E.R. (2013), "PPPs and Project Finance" in de Vries, P. and Yehoue, E.B., (Eds.), The Routledge Companion to Public-Private Partnerships, Routledge, Abingdon.

Yescombe, E.R. (2014), Principles of Project Finance, Academic Press, London.

Yescombe, E.R. and Farquharson, E. (2018), Public-Private Partnerships in Infrastructure, Elsevier, London.

\section{About the author}

Laura Panadès-Estruch is a leading researcher in Public Procurement and Public-Private Partnerships (PPPs) in the Caribbean. She is LLM Director in International Finance and Lecturer at Truman Bodden Law School of the Cayman Islands, in partnership with the University of Liverpool (UK). She is a PhD candidate in Law at the University of Cambridge. She has ten years of experience in public procurement, and is a member of the Cayman Islands Public Procurement Committee. She has also worked for the European Parliament, and the European Commission H2020 DIGIWHIST project for early detection of corruption. She holds a Master of Laws (Distinction), an LLB in Law and a BSc in Business Administration and Management from Pompeu Fabra University, Spain. Laura Panadès-Estruch can be contacted at: laura.panades@ gov.ky

For instructions on how to order reprints of this article, please visit our website:

www.emeraldgrouppublishing.com/licensing/reprints.htm

Or contact us for further details: permissions@emeraldinsight.com 